\title{
"Climate change and agricultural development in West Africa: Role of renewable energy and trade openness"
}

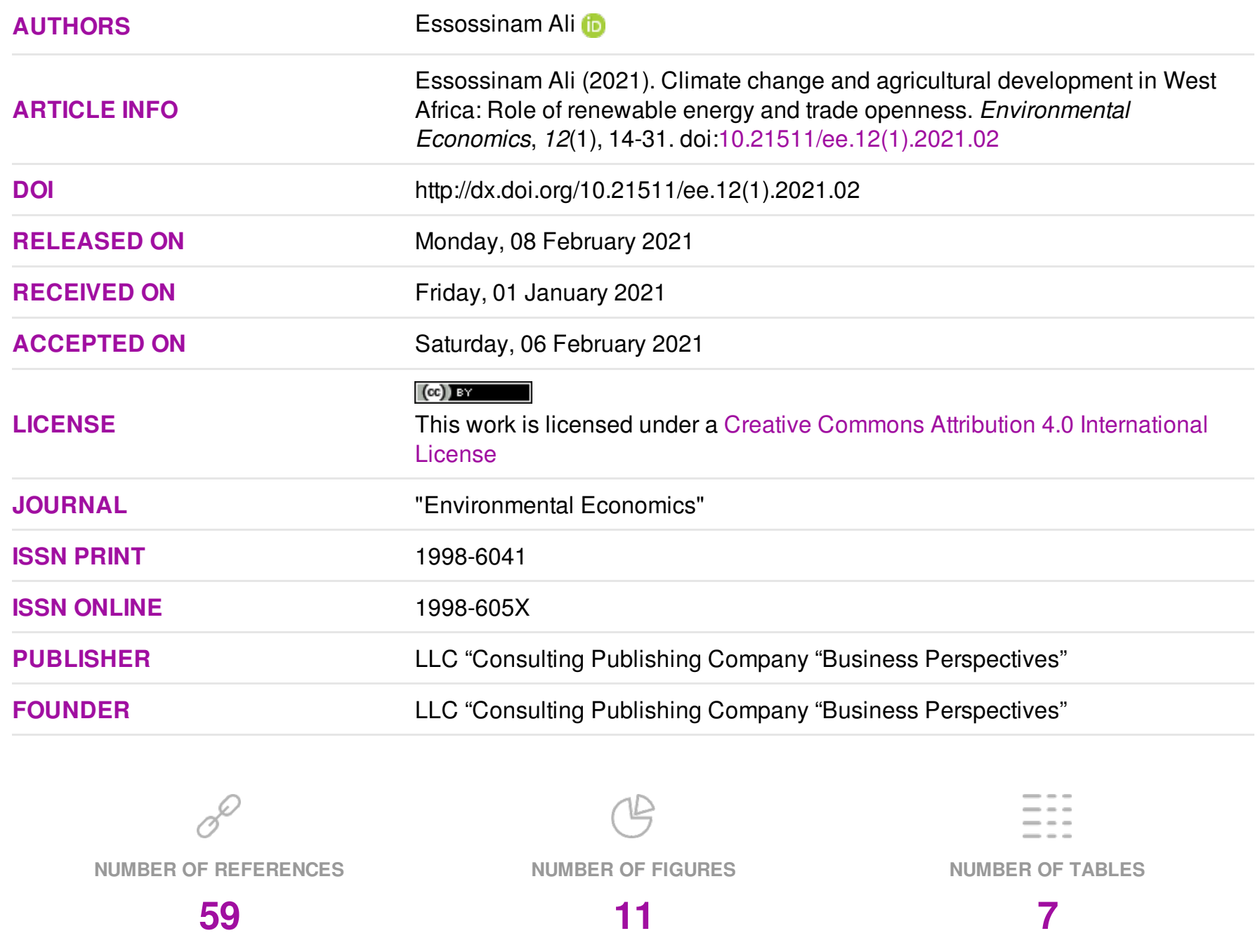

(C) The author(s) 2022. This publication is an open access article. 


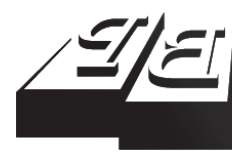

\section{BUSINESS PERSPECTIVES}

9

LLC "CPC "Business Perspectives"

Hryhorii Skovoroda lane, 10,

Sumy, 40022, Ukraine

www.businessperspectives.org
Received on: $1^{\text {st }}$ of January, 2021 Accepted on: $8^{\text {th }}$ of February, 2021 Published on: $8^{\text {th }}$ of February, 2021

(C) Essossinam Ali, 2021

Essossinam Ali, Faculty of Economic and Management Sciences, Department of Economics, University of Kara, Togo.

Essossinam Ali (Togo)

CLIMATE CHANGE AND AGRICULTURAL DEVELOPMENT IN WEST AFRICA: ROLE OF RENEWABLE ENERGY AND TRADE OPENNESS

\begin{abstract}
The design, implementation, and evaluation of energy policies in combating climate change are becoming increasingly evident to strengthen economic growth driven by the agricultural sector in most developing countries. The study analyzes the direct and indirect effects of renewable energy consumption (REC) on agriculture value-added ( $\mathrm{AgVA}), \mathrm{CO} 2$ emissions, and trade openness in the short- and long-run in the West African countries. The second-generation panel unit root tests, the panel cointegration methods, and Panel Vector Error Correction Model are used with World Bank data from 1990 to 2015. A panel Granger causality test was also used to determine the direction of causality between variables. Findings show a unidirectional relationship between AgVA, CO2 emissions, and REC; between REC, gross fixe capital formation (GFCF) and trade openness. Moreover, the bidirectional hypothesis is verified between agricultural development and trade openness. However, the null hypothesis is found between AgVA and GFCF, on the one hand, and GFCF and CO2 emissions, on the other hand. These results suggest that fostering renewable energy policy and revisiting trade policy toward reducing environmental pollution will enable agricultural development and boost the regional economy.
\end{abstract}

Keywords

JEL Classification O13, Q27, Q56

\section{INTRODUCTION}

The role of renewable energy (RE) in economic development and its environmental benefits in terms of climate risk management has increased interest in recent debates around the world (Bayale et al., 2021; Frangou et al., 2018; Rafindadi \& Ozturk, 2017; Liu et al., 2017a). According to Liu et al. (2017a) and Heidari and Pearce (2016), RE can be a key instrument in climate change adaptation and mitigation. It is well recognized that $\mathrm{CO}_{2}$ emissions using $\mathrm{RE}$ technology are less than traditional energy supply sources (Liu et al., 2017a; Ben Jebli \& Ben Yousef, 2015; Heidari \& Pearce, 2016). Increasing investment in RE production and consumption could be more economically beneficial and more viable than non-renewable energy use (Frangou et al., 2018; Kahia et al., 2017; Rafindadi \& Ozturk, 2017). For example, Frangou et al. (2018) have estimated that saving from renewable energy consumption (REC) could be ranged from 3\% to $23 \%$ on energy costs in the case study of Greece. According to Miketa and Merven (2013), the share of RE technologies will increase from $22 \%$ to $52 \%$ of current electricity generation in West Africa, with $46 \%$ of adding capacity by 2030. The use of RE as part of sustainable development goals is said to contribute significantly to poverty reduction and countries' develop- 
ments. The REC could boost the rural households' economies and enhance job creation opportunities, while the non-access to energy would severely affect economic growth (Schwerhoff \& Sy, 2017; InglesiLotz, 2016; Birol, 2007).

Despite many studies in energy economics, there are still debates on the effect and relationship direction between REC and economic growth. Four hypotheses are often discussed:

(I) the neutrality assumption, which does not support any relationship between energy use and economic growth;

(II) the unidirectional assumption between economic growth and energy consumption;

(III) the growth hypothesis, which strongly agrees that energy consumption leads to economic growth; and

(IV) feedback assumption, which assumes that energy consumption positively affects economic growth, and vice versa (Brini et al., 2017; Ben Jebli \& Ben Yousef, 2017).

The specific energy policy could depend not only on the type of hypothesis but also on the geographical position of the region and the main drive of countries' economies. In the context of globalization, trade openness that eases RE technology transfer can also lead to new empirical insights and policy implications. While the agricultural sector remains the main wagon of West African countries' economies (more than 35\% of GDP), not much attention has been given to investigating the relationship between $\mathrm{REC}, \mathrm{CO}_{2}$ emissions, and agricultural development in the energy economics of the region. Moreover, while trade openness can be a catalyst in RE transfer, it can be a source of pollution in the context of globalization in regions with non-binding environmental laws such as West African countries, and therefore, more investigations are needed.

This study fills this research gap in the empirical literature by analyzing the dynamici between climate change captured by $\mathrm{CO}_{2}$ emissions and agricultural development in West African countries while highlighting the role of renewable energy and trade openness. Specifically, this research assesses the short and long-run effects of REC and trade openness on agricultural development in West African countries. It also investigates the causality direction between REC, $\mathrm{CO}_{2}$ emissions, and agricultural development in the short- and long-run in the study areas. The results will help foster the design and implementation of an energy policy that encourages the creation and promotion of small-scale enterprises that work to develop renewable energy technology in the region. This study is also in line with the Sustainable Development Goals (SDG) agenda that seeks to ensure efficiency in terms of affordability and accessibility of energy by 2030. The study will increase agricultural productivity in the region through energy use while combating climate change by reducing $\mathrm{CO}_{2}$ emissions.

\section{LITERATURE REVIEW}

Natural resources such as energy must be managed so that future generations could benefit, while its consumption is expected to meet the needs of the population as defined sustainable development by Brundtland (1987). Indeed, the theory of sustainable development might find its origin after Meadows et al. (1972) demonstrate that economic growth could be limited if resources are not ra- tionally or efficiently used. Since then, the theory of green growth and sustainable development in the production process has gained researchers' attention in the context of climate change and agricultural development (Zaccour \& Oubraham, 2018; Reilly, 2012). It is societies' and policymakers' responsibility to think about the effects of today's actions on future generations. This refers to the concept of energy efficiency. The use of RE is then highly motivated for agricultural sustainability in 
a green growth perspective (Chel \& Kaushik, 2011; Adelaja \& Hailu, 2008). It is an example of agricultural land and other factors such as environment, biomass, and water resources. For instance, agriculture, which is the main source of production and livelihood of most of the population, contributes significantly to the $\mathrm{CO}_{2}$ emissions (Liu et al., 2017a; Ben Jebli \& Ben Youssef, 2015). This leads to the rethinking of sustainability in the agricultural production process, hence the green economy concept. The green economy concept includes the trade-off between RE and non-renewable energy consumption that would have a strong link with economic growth (Bayale et al., 2021; Lyytimäki, 2018; Sutherland et al., 2015). Martinho (2018) and Sutherland et al. (2015) showed that agriculture has an important role in the green economy as a key sustainable development strategy. Energy security relies on the affordability of energy but must consider the technological change (Proskuryakova, 2018).

The economic advantage that offers REC and the volatile nature of energy prices affecting global economies led to countries' setting up the roadmaps of $100 \%$ of REC (Sadiqa et al., 2018; Hohmeyer \& Bohm, 2015). REC must be encouraged in developing countries, given the rapid population growth and urbanization that could increase energy demand, which is forecasted to increase by $100 \%$ on the global scale and more than $120 \%$ in some countries, such as Russia and Brazil by 2050 (Resch et al., 2008). This is evident in West African countries where the population is expected to increase by $2.5 \%$ per annum by 2050 , increasing $\mathrm{CO}_{2}$ emissions from human activities and electricity generation technologies from non-renewable energy sources. Despite the contribution of energy to economic growth, the International Renewable Energy Agency (IRENA, 2018) has reported that the current state of energy consumption is alarming in West African countries. For instance, the average rate of electricity access per capita ranges between $9 \%$ and $72 \%$, with most countries less than 30\% (IRENA, 2018) compared to 98\% in North Africa (IRENA, 2015). Also, the International Energy Agency (IEA) (2014) has reported that West Africa is the only region in the world where the number of people living without electricity is increasing. Investing in RE technology adoption in the region could help reduce the energy gap and boost economic growth driven by the agriculture sector.

Adelaja and Hailu (2008) found that using wind energy in the Michigan agricultural sector could increase farm net revenue by $50 \%$. Similarly, Paramati et al. (2018) found that REC has positively impacted economic activities, including agriculture, more than non-renewable energy. Whatever it comes from a renewable or non-renewable source, the energy constitutes a key input in the agricultural production process. During crop production and processing, RE use can directly or indirectly play an important role (transport of agricultural inputs, harvesting, packing, seeding and irrigation, poultry production, and transformation of animals' derived products). It can also help manage post-harvest losses (grain drying, food transformation, storage, and conservation). As a result, agriculture and its value chain actors could be highly vulnerable to the variability of fuel prices on the international market (Farajian et al., 2018; Martinho, 2016) if based production more on non-renewable energy consumption. Turkey's case study by Bayrakci and Koçar (2012) showed a high trade surplus estimated at EUR 1.5 billion because of REC in agriculture.

Renewable energy use is an encouraging option in combating climate change induced by an increase in $\mathrm{CO}_{2}$ emissions from fossil fuel consumption. For example, agriculture is seen as the main source of $\mathrm{CO}_{2}$ emissions. Simultaneously, using RE will reduce $\mathrm{CO}_{2}$ emissions and increase agricultural value-added higher than the conventional energy impact (Wesseh \& Lin, 2016). The countries' dependency on fossil fuel imports and the increase in power costs because of rising demand are other reasons that support RE policy redesign, especially in Sub-Saharan Africa, where $90 \%$ of the population still do not have access to electricity (IRENA, 2018). For instance, the use of fossil fuels, pesticides, and synthetic fertilizer in agriculture could increase production costs and destroy progressively agricultural ecosystems and increase environmental damage with decreasing farm profitability in the long run because of the degradation of natural soil nutrients. Chel and Kaushik (2011) found that the use of wind energy could reduce $\mathrm{CO}_{2}$ emissions by approximately 0.9 tons per year. For sustainable agriculture, the 
use of RE could combat pollution, encourage the use of clean technologies, and facilitate the use of water pumps for irrigation (Chel \& Kaushik, 2011).

Whether theoretically or empirically, the energy policy and recommendations for economic development among decision-makers are not unanimous. The results depend on whether one considers the short- or long-run patterns, the area of study, or the methods adopted for the typical study. Using the Granger causality test, Ben Jebli and Ben Youssef (2017) found the unidirectional causality between economic growth and REC and agricultural value-added, non-REC and agricultural value-added, and between $\mathrm{CO}_{2}$ emissions and $\mathrm{RE}$ in the short run. Moreover, the feedback hypothesis was found between agricultural value-added and $\mathrm{CO}_{2}$ emissions, while the U-shaped environmental curve hypothesis was not verified. The bidirectional assumption was not supported in the case study of OECD countries (Alp, 2016). Using the vector autoregressive model, Johansen cointegration, and Granger causality test, Alp (2016) found heterogeneous results between countries within the OECD region. There was no evidence of the relationship between energy consumption and economic development in eleven countries, while the growth hypothesis that strongly agrees on the energy consumption and economic growth nexus was satisfied within 6 countries only (Alp, 2016).

The heterogeneity characteristic of the effects of $\mathrm{RE}$ on economic growth was also found by Bhattacharya et al. (2016). A significant and positive effect of RE on economic development was found for $57 \%$ of the selected countries (Bhattacharya et al., 2016). Also, using quarterly time-series data, Rafindadi and Ozturk (2017) point out that REC, capital, and labor productivity could strengthen the German economy. The bidirectional effects between RE and economic growth were found. Considering the multivariate panel framework, Kahia et al. (2017) found the long-run relationship between REC, non-renewable energy consumption, labor force, and gross capital formation over 1980-2012. Bidirectional causality was found between REC and economic growth, non-renewable energy consumption, and economic growth using the panel error correction model (Kahia et al., 2017). However, not much attention has been given to the nexus between climate change, REC, trade openness, and agricultural development within the West African countries that promote regional integration for several decades. The study will expand the literature to foster regional energy policy for sustainable development.

\section{METHODS}

Several methods have been used to assess the socioeconomic impact of REC and environmental management. The methods used to analyze the energy demand and supply and the impact assessment of energy transition depend on whether one considers the national or regional scales (Farajian et al., 2018; Jenniches, 2018; Khan et al., 2018; Bhattacharya et al., 2016). The production function is often served as the theoretical foundation in analyzing REC and economic growth nexus (Bhattacharya et al., 2016; Inglesi-Lotz, 2016). The model applied depends on the econometric tests required and the data used. Based on the green growth theory developed by Hickel and Kallis (2020), the neoclassical production function in which some inputs are used to produce a certain level of output is used. Assume that the agricultural development captured by the agricultural value-added $(A g V A)$ is mainly affected by greenhouse gas emissions (CO2), trade openness (Trade), and renewable energy consumption $(R E C)$ while controlling for other variables $(X)$. Then, it follows:

$$
A g V A_{i t}=f\left(R E C_{i t}, C O 2_{i t}, \operatorname{Trade}_{i t}, X_{i t}, \varepsilon_{i t}\right) .
$$

Trade openness (Trade) represents the ratio of exports and imports to GDP. Gross fixed capital formation (GFCF) representing domestic investment is used as a control variable. In equation (1), $i$ represents the country $(i=1 \ldots 12)$ and $t$ is the year $(t=1990 \ldots$ 2015). The choice of variables is based on the literature and the study period depends on the availability of the data. Assuming that the specific functional form of equation (1) is the CobbDouglas production function, equation (1) could be rewritten in the linear form as follows:

$$
\begin{aligned}
& \ln \mathrm{AgVA}_{i t}=\vartheta_{i}+\varphi_{1 i} \ln \mathrm{CO}_{i t}+ \\
& +\varphi_{2 i} \ln \operatorname{REC}_{i t}+\varphi_{3 i} \ln \text { Trade }_{i t}+ \\
& +\varphi_{4 i} G F C F_{i t}+\delta_{i} t+\varepsilon_{i t},
\end{aligned}
$$


where $\varepsilon_{i t}$ is the error term, $\vartheta_{i}$ is a column vector capturing the country-specific effect, and $t$ is the deterministic time trend lasting from 1990 to 2015. $\varphi$ and $\theta$ are the vectors of parameters to be estimated.

The cross-sectional dependence within individuals in panel data may be occurred because of common shocks due to a strong economic integration within countries (for example, the regional energy policy of ECOWAS, the common agricultural policy in WAEMU (ECOWAS and WAEMU are sub-regional blocs within the West African countries), coronavirus disease (COVID-19) or spatial dependence (WAEMU countries versus non-WAEMU countries; two sub-regional groups within ECOWAS). Ignoring this cross-sectional dependence within units by incorporating it into the error term will lead to an inconsistent estimate (Hoyos \& Sarafidis, 2006). To check the cross-sectional dependency within individuals (countries), Pesaran CD test and Breusch-Pagan test (Breusch \& Pagan, 1980) are mostly used (Bhattacharya et al., 2016). In this study, the number of individuals (13) is less than the time dimension (26 years). In that case, instead of Pesaran CD test, Breusch-Pagan test used to check for cross-sectional dependence within countries is a better fit. If the hypothesis of the cross-dependency within variables is verified, the panel unit root test will be applied using the second-generation test suggested by Pesaran (2007). The null hypothesis is that there is homogenous non-stationarity. If one fails to reject the null hypothesis of the existence of panel unit root, it means the variances of the time series are unstable over time leading probably to the long-run relationships between variables. In that case, the panel error correction model (PVCM) will be useful. The PVCM equations are stated as follows:

$$
\left[\begin{array}{l}
\Delta \ln A g V A_{i t} \\
\Delta \ln C O_{2 i t} \\
\Delta \ln R E C_{i t} \\
\Delta \operatorname{Trade}_{i t} \\
\Delta G F C F_{i t}
\end{array}\right]=\left[\begin{array}{l}
\alpha_{1} \\
\alpha_{2} \\
\alpha_{3} \\
\alpha_{4} \\
\alpha_{5}
\end{array}\right]+\sum_{k=1}^{p}\left[\begin{array}{lllll}
\vartheta_{11 p} & \vartheta_{12 p} & \vartheta_{13 p} & \vartheta_{14 p} & \vartheta_{15 p} \\
\vartheta_{21 p} & \vartheta_{22 p} & \vartheta_{23 p} & \vartheta_{24 p} & \vartheta_{25 p} \\
\vartheta_{31 p} & \vartheta_{32 p} & \vartheta_{33 p} & \vartheta_{34 p} & \vartheta_{35 p} \\
\vartheta_{41 p} & \vartheta_{42 p} & \vartheta_{43 p} & \vartheta_{44 p} & \vartheta_{45 p} \\
\vartheta_{51 p} & \vartheta_{52 p} & \vartheta_{53 p} & \vartheta_{54 p} & \vartheta_{55 p}
\end{array}\right] \times\left[\begin{array}{l}
\Delta \ln A g V A_{i t-1} \\
\Delta \ln C O_{2 i t-1} \\
\Delta \ln R E C_{i t-1} \\
\Delta \operatorname{Trade}_{i t-1} \\
\Delta G F C F_{i t-1}
\end{array}\right]+\left[\begin{array}{c}
\delta_{1} \\
\delta_{2} \\
\delta_{3} \\
\delta_{4} \\
\delta_{5}
\end{array}\right] E C T_{i t-1}+\left[\begin{array}{l}
\mu_{1 i t} \\
\mu_{2 i t} \\
\mu_{3 i t} \\
\mu_{4 i t} \\
\mu_{5 i t}
\end{array}\right] .
$$

In equation (3), $\Delta$ stands for the first difference of each variable. The long-term relationship between variables is captured by the error correction term and represented by $E C T_{i t-1}$. In equation (3), $\mu$ stands for the random error term.

The study covers 13 countries in West Africa, and the data from the World Bank Indicator (WDI, 2020 ) are used. The economic growth was, on average, about $3.86 \%$ per year. The agricultural sector was the main driver of economic growth and reached about $61.41 \%$ of GDP. It accounted on average for $30.38 \%$ of gross domestic product (GDP) throughout 1990-2015 (Table 1).

The renewable energy consumption (REC) in the region has reached an average of $72.17 \%$ of total final energy consumed in West African countries. This would significantly influence agricultural development through direct use for agricultural production and reduce $\mathrm{CO}_{2}$ emissions (climate change). $\mathrm{CO}_{2}$ emissions, which are the main components of greenhouse gas, could also directly or indirectly affect the region's economic growth. The average $\mathrm{CO}_{2}$ emissions in the selected countries reached a maximum of 106 thousand kilotons. The trade openness reached about $62.07 \%$ of GDP.

Nigeria and Ghana, the leading economies of the region, have the highest economic growth $(5.11 \%$ and $5.38 \%$, respectively), while Guinea Bissau, Ivory Coast, and Sierra Leone have the lowest rate of economic growth $(2.33 \%, 2.55 \%$, and $2.82 \%$, respectively). The average agricultural value-added in the leading economy of West Africa reached annually $24.81 \%$ for Nigeria and $33.22 \%$ for Ghana. The agricultural sector has an important contribution to GDP in the overall selected countries with more significance in Sierra Leone (49.02\% of GDP) followed by Guinea-Bissau (47.39\% of 
Table 1. Average annual of the variables used in the study (1990-2015)

\begin{tabular}{|c|c|c|c|c|c|c|}
\hline Countries & GDP & AgVA & REC & Trade & GFCF & $\mathrm{CO}_{2}$ \\
\hline Benin & 4.52 & 27.18 & 69.09 & 55.94 & 20.50 & 2852.46 \\
\hline Burkina Faso & 5.36 & 32.52 & 85.25 & 39.31 & 21.87 & 1344.14 \\
\hline Ivory Coast & 2.55 & 25.12 & 72.49 & 78.11 & 11.75 & 6963.26 \\
\hline Gambia & 3.33 & 21.58 & 58.13 & 64.51 & 15.10 & 295.75 \\
\hline Ghana & 5.38 & 33.22 & 64.47 & 75.98 & 20.79 & 7728.04 \\
\hline Guinea & 3.75 & 19.04 & 82.92 & 61.40 & 20.50 & 1795.66 \\
\hline Guinea-Bissau & 2.33 & 47.39 & 88.54 & 49.55 & 15.89 & 203.82 \\
\hline Mali & 4.43 & 34.79 & 80.36 & 55.59 & 19.17 & 794.16 \\
\hline Mauritania & 3.83 & 28.29 & 40.16 & 92.46 & 30.50 & 1581.00 \\
\hline Nigeria & 5.11 & 24.81 & 86.29 & 38.62 & 29.62 & 73652.05 \\
\hline Senegal & 3.58 & 15.64 & 47.89 & 61.04 & 21.33 & 5055.58 \\
\hline Sierra Leone & 2.82 & 49.02 & 85.99 & 53.41 & 11.71 & 640.45 \\
\hline Togo & 3.22 & 35.36 & 76.68 & 80.91 & 16.19 & 1532.21 \\
\hline West Africa & 3.86 & 30.38 & 72.17 & 62.07 & 19.61 & 8033.74 \\
\hline
\end{tabular}

GDP). However, Burkina Faso has the highest agricultural value addition (32.52\%) and economic growth within the West African Economic Monetary Union (WAEMU), a sub-regional group of West Africa, sharing the common currency (the Franc CFA). The proportion of REC of the total energy used in West Africa was relatively high in countries such as Sierra Leone (85.99\%), Nigeria (86.29\%), Guinea-Bissau (88.54\%), Mali (80.36\%), and Burkina Faso (85.25\%). The gross fixed capital formation (GFCF) that captures the investment level reached on average $30.50 \%$ of GDP in Mauritania, while it was only about $11.71 \%$ in Sierra Leone over the study period. However, Nigeria has the highest level of $\mathrm{CO}_{2}$ emissions (73652.05 kt) and low level observed in Guinea-Bissau (203.82 kt). This can be explained by the level of economic development of each country, as highlighted by Kuznets (1955).

\section{RESULTS}

The correlation between variables and the multicollinearity test are provided in Table 2 . The average variance inflation factors $(V I F=1.31)$ are less than $5 \%$ showing that multicollinearity between the considered variables is not a problem in the estimation process (O’Brien, 2007). Table 2 shows a positive correlation between REC and agricultural development $(A g V A)$. The econometrics tests would shed light on the causality between these variables. However, a high and negative correlation between REC and trade openness was observed (Table 2).
Table 2. Correlation between variables and multicollinearity test

\begin{tabular}{l|c|c|c|c|c}
\hline Variables & AgVA & REC & CO $_{\mathbf{2}}$ & GFCF & Trade \\
\hline AgVA & 1 & - & - & - & - \\
\hdashline REC & 0.49 & 1 & - & - & \\
\hdashline CO2 & -0.18 & 0.16 & 1 & - & - \\
\hdashline GFCF & -0.24 & -0.26 & 0.18 & 1 & - \\
\hline Trade & -0.17 & -0.52 & -0.26 & 0.20 & 1 \\
\hdashline VIF (in \%) & - & 1.45 & 1.16 & 1.17 & 1.48 \\
\hdashline Mean VIF & 1.31 & & & & \\
\hline
\end{tabular}

Moreover, there was a negative and low correlation between gross fixed capital formation and REC. This suggests a probable substitution between the use of renewable energy and investment captured by gross fixed capital formation. Given the individuals and the time dimension, the BreuschPagan test was a better fit to check the existence of cross-sectional dependence within countries (Table 3).

Table 3. Breusch-Pagan test of independence

\begin{tabular}{l|c|c}
\hline \multicolumn{1}{c|}{ Variables } & $\begin{array}{c}\text { Chi-squared } \\
\text { statistics }\end{array}$ & $\boldsymbol{p}$-value \\
\hline $\mathrm{AgVA}$ & $330.124^{* * *}$ & 0.0000 \\
\hline REC & $768.506^{* * *}$ & 0.0000 \\
\hline $\mathrm{CO}$ & $1422.923^{* * *}$ & 0.0000 \\
\hline GFCF & $299.576^{* * *}$ & 0.0000 \\
\hline Trade & $242.946^{* * *}$ & 0.0000 \\
\hline
\end{tabular}

Note: $(* * *)$ indicates the significance level at $1 \%$.

The results show that the probability values of all variables are less than $1 \%$ level. This implies that the hypothesis of cross-sectional dependency 
within individuals cannot be rejected. Therefore, the first generation test of panel unit roots is no longer appropriate. Thus, the second-generation panel unit root tests will be applied. The author showed a cross-sectional dependence between individuals. In that case, the second-generation test of panel unit root proposed by Pesaran (2007) is the most appropriate (Table 4).

Table 4. Pesaran panel unit root test with cross-sectional

\begin{tabular}{l|c|c|c|c}
\hline \multirow{2}{*}{ Variable } & \multirow{2}{*}{ CIPS } & \multicolumn{3}{|c}{ Critical value } \\
\cline { 2 - 5 } & & $\mathbf{1 0 \%}$ & $\mathbf{5 \%}$ & $\mathbf{1 \%}$ \\
\hline InAgVA & -2.744 & -2.66 & -2.76 & -2.96 \\
\hline InREC & -2.173 & -2.14 & -2.25 & -2.45 \\
\hdashline $\operatorname{In} C O$ & -2.355 & -2.14 & -2.25 & -2.45 \\
\hdashline GFCF & -2.805 & -2.66 & -2.76 & -2.96 \\
\hline InTrade & -2.132 & -2.14 & -2.25 & -2.45 \\
\hline
\end{tabular}

The null hypothesis states that all variables are homogeneous non-stationary. The alternative hypothesis is that the time series is stationary, and the integration of variables is no longer important. The results show that the Pesaran statistic values (CIPS) are all greater than the critical values for all variables at least at $1 \%$ level. This result suggests that all variables need to be integrated because they are non-stationary at the level. To check the existence of the long-run relationship between variables, Westerlund panel cointegration tests were used (Westerlund, 2007). This test is more appropriate than the cointegration test performed by Perdoni (1999) since there is a cross-sectional dependence between individuals. This test assumes that there is no cointegration between variables. The results show that all statistics are significant, at least at a 5\% level, including the robust $p$-values (Table 5).

Table 5. Westerlund ECM panel cointegration tests

\begin{tabular}{|c|c|c|c|c|}
\hline Variable & Statistics & Value & Z-value & $\begin{array}{l}\text { Robust } \\
p \text {-value }\end{array}$ \\
\hline \multirow{4}{*}{ AgVA } & Gt & $-5.008 * * *$ & -11.908 & 0.000 \\
\hline & $\mathrm{Ga}$ & $-31.848^{* * *}$ & -10.814 & 0.000 \\
\hline & $\mathrm{Pt}$ & $-18.209 * * *$ & -12.336 & 0.000 \\
\hline & $\mathrm{Pa}$ & $-31.641^{* * *}$ & -13.695 & 0.000 \\
\hline \multirow{4}{*}{ REC } & $\mathrm{Gt}$ & $-3.861 * * *$ & 6.756 & 0.000 \\
\hline & $\mathrm{Ga}$ & $-27.839 * * *$ & 8.641 & 0.010 \\
\hline & $\mathrm{Pt}$ & $-13.099 * *$ & 6.384 & 0.020 \\
\hline & $\mathrm{Pa}$ & $-22.964 * *$ & 8.457 & 0.040 \\
\hline
\end{tabular}

Note: $(* * *)$ indicates the significance level at $1 \%,(* *)$ is the significance level at $5 \%$.
This implies that the null hypothesis of the absence of cointegration can be rejected, hence the existence of a long-run cointegration among variables. However, the stability of this long-run relationship should be tested. The Granger causality test results show a unidirectional causality, running from REC to agricultural value-added (Table 6).

The Granger causality test shows that a bidirectional hypothesis is verified between agricultural value-added and trade openness. Therefore, any change in trade openness will affect agricultural value-added and vice-versa. On the one hand, this result can be explained by the fact that most agricultural products in West Africa are exported as raw materials (cotton, cocoa, coffee, cashew, rubber) and the subject of important revenues. Alternatively, West African countries are net importers of most transformed agricultural goods, and trade openness can facilitate transactions. This result was also supported by Ben Jebli and Ben Youssef (2015). Similar results were found in the literature (Raeeni et al., 2019; Brini et al., 2017; Marques \& Fuinhas, 2011) but contradict Liu et al. (2017) who show a positive relationship between REC and trade openness.

Raeeni et al. (2019) found no causality between trade and REC in the Iranian case study, while Marques and Fuinhas (2017) found that the market was not a determinant of renewable energy use in the case study of 24 European countries. The results also showed no causality between trade openness and $\mathrm{CO}_{2}$ emissions. This result is similar to Raeeni et al. (2019), but contradicts Ben Jebli and Ben Youssef (2015) who found that trade openness may be a source of global warming as a transaction in transportation traded goods may lead to more $\mathrm{CO}_{2}$ emissions. The results show that the long-run coefficients of agricultural value-added, REC, and trade openness are significant at a $1 \%$ level (Table 7). It implies that the three models out of five have a long-run relationship.

The negative sign is associated with agricultural value-added and trade openness, while it is positive for the REC. This suggests that trade openness will not favor agricultural development in West African countries in the long run. The adjustment amount of REC from short-run to long-run is 0.076 . This suggests that the previous shocks on agricultural value-added, $\mathrm{CO}_{2}$ emissions, gross 
Table 6. Granger causality test

\begin{tabular}{|c|c|c|c|c|c|}
\hline Variable & AgVA & REC & $\mathrm{CO}_{2}$ & Trade openness & GFCF \\
\hline AgVA & - & $\begin{array}{l}\text { Unidirectional } \\
\text { causality between } \\
R E C \text { and } A g V A\end{array}$ & $\begin{array}{l}\text { Unidirectional } \\
\text { causality between } \\
\mathrm{CO}_{2} \text { and } \mathrm{AgVA}\end{array}$ & $\begin{array}{l}\text { Bidirectional causality } \\
\text { between Trade openness and } \\
\text { AgVA }\end{array}$ & No causality \\
\hline REC & $\begin{array}{l}\text { Unidirectional } \\
\text { causality between } \\
\text { REC and AgVA }\end{array}$ & - & No causality & No causality & $\begin{array}{l}\text { Unidirectional } \\
\text { causality between } \\
\text { GFCF and REC }\end{array}$ \\
\hline $\mathrm{CO}_{2}$ & $\begin{array}{l}\text { Unidirectional } \\
\text { causality between } \\
\mathrm{CO}_{2} \text { and } \mathrm{AgVA}\end{array}$ & No causality & - & No causality & No causality \\
\hline $\begin{array}{l}\text { Trade } \\
\text { openness }\end{array}$ & $\begin{array}{c}\text { Bidirectional causality } \\
\text { between Trade } \\
\text { openness and AgVA }\end{array}$ & No causality & No causality & - & $\begin{array}{c}\text { Unidirectional } \\
\text { causality between } \\
\text { GFCF and Trade } \\
\text { openness }\end{array}$ \\
\hline GFCF & No causality & $\begin{array}{l}\text { Unidirectional } \\
\text { causality between } \\
\text { GFCF and } R E C\end{array}$ & No causality & $\begin{array}{c}\text { Unidirectional causality } \\
\text { between GFCF and Trade } \\
\text { openness }\end{array}$ & - \\
\hline
\end{tabular}

fixed capital formation, and trade openness will increase the demand for renewable energy by $7.6 \%$ in the long run. This can be achieved by increasing the investment in renewable energy production significantly (Bayale et al., 2021; Le \& Van, 2020; Liu et al., 2017; Rafindadi \& Ozturk, 2017). The evidence is that there is a unidirectional relationship between GFCF and REC in the short run, indicating that the GFCF is a determinant of renewable energy use. However, the results indicate that any shocks in the previous periods could have negatively resulted in agricultural growth and trade openness at the long-run equilibrium. These shocks might be climate change (increase in $\mathrm{CO}_{2}$ emissions), low investment in renewable energy production, or the pollution from globalization that is prone to trade openness (Schwerhoff \& Sy, 2017; Ben Jebli \& Ben Youssef, 2017).

\section{DISCUSSION}

This result suggests that any REC change has an immediate impact on agricultural development

Table 7. Panel Vector Error Correction Model (PVCM) estimating long-run causality

\begin{tabular}{|c|c|c|c|c|c|}
\hline Variables & $\Delta(\ln A g V A)$ & $\Delta\left(\ln \mathrm{CO}_{2}\right)$ & $\Delta(\ln R E C)$ & $\Delta(\ln T r a d e)$ & InGFCF \\
\hline \multicolumn{6}{|c|}{ Long-run } \\
\hline \multirow{2}{*}{$E C_{t-1}$} & $-1.099 * * *$ & 0.161 & $0.076 * * *$ & $-0.506 * * *$ & 3.996 \\
\hline & $(0.082)$ & $(0.123)$ & $(0.036)$ & $(0.146)$ & (3.943) \\
\hline \multicolumn{6}{|c|}{ Short-run } \\
\hline \multirow{2}{*}{$\Delta\left(\ln A g V A_{t-1}\right)$} & 0.053 & -0.100 & -0.033322 & $0.340 * * *$ & -1.572 \\
\hline & $(0.056)$ & $(0.084)$ & $(0.025)$ & $(0.100)$ & $(2.702)$ \\
\hline \multirow{2}{*}{$\Delta\left(\operatorname{lnCO2}{ }_{t-1}\right)$} & $-0.100 * * *$ & $-0.470 * * *$ & -0.019 & -0.0096 & -1.274 \\
\hline & $(0.040)$ & $(0.060)$ & $(0.018)$ & $(0.071)$ & $(1.932)$ \\
\hline \multirow{2}{*}{$\Delta\left(\ln R E C_{t-1}\right)$} & $-0.467 * * *$ & 0.037 & $-0.518^{* * *}$ & -0.313 & -4.496 \\
\hline & $(0.121)$ & $(0.182)$ & $(0.054)$ & $(0.216)$ & $(5.808)$ \\
\hline \multirow{2}{*}{$\Delta\left(\ln\right.$ Trade $\left._{t-1}\right)$} & $0.163 * * *$ & -0.044 & -0.015 & $-0.444^{* * *}$ & -0.155 \\
\hline & $(0.030)$ & $(0.046)$ & $(0.013)$ & $(0.054)$ & $(1.467)$ \\
\hline \multirow{2}{*}{$\ln G F C F_{t-1}$} & 0.001 & -0.002 & $0.001^{* * *}$ & $-0.004^{* *}$ & $-0.192^{* * *}$ \\
\hline & $(0.001)$ & $(0.001)$ & $(0.001)$ & $(0.002)$ & $(0.058)$ \\
\hline \multirow{2}{*}{ C } & 0.002 & -0.010 & -0.001 & 0.0001 & 0.146 \\
\hline & $(0.006)$ & (0.009) & $(0.002)$ & $(0.011)$ & $(0.307)$ \\
\hline$R^{2}$ & 0.5119 & 0.2083 & 0.2825 & 0.3579 & 0.4550 \\
\hline Adj. $R^{2}$ & 0.5019 & 0.1920 & 0.2678 & 0.3447 & 0.2590 \\
\hline
\end{tabular}

Note: $\left({ }^{* *}\right)$ indicates the significance level at $1 \%,(* *)$ is the significance level at $5 \%$. 
in the West African region. Similar results were found by Raeeni et al. (2019) in the Iranian case study and by Ouedraogo (2013) in WAEMU countries. In achieving sustainable development goals in West Africa, the role of RE in agricultural development recalls attention on financing RE (Raeeni et al., 2019; Schwerhoff \& Sy, 2017). Moreover, the results indicate that the unidirectional hypothesis is verified between AgVA and $\mathrm{CO}_{2}$ emissions. This causality runs from $\mathrm{CO}_{2}$ emissions to agricultural value-added. This result implies that climate change induced by an increase in $\mathrm{CO}_{2}$ emissions could directly impact agricultural value-added. This result corroborates most studies recognizing the pronounced impacts of climate change on crop productivity in West African countries (Ali et al., 2020; Parkes et al., 2018; Ali, 2018). However, the bidirectional hypothesis was verified in the case study by Ben Jebli and Ben Youssef (2015) in Tunisia. The results show that the unidirectional hypothesis is verified between REC and gross fixed capital formation (GFCF) running from GFCF to REC, on the one hand, and trade openness and GFCF running from GFCF to trade openness, on the other hand. This implies that any change in investment level will affect renewable energy consumption and trade openness. Indeed, an increase in investment level might increase renewable energy technologies adoption, therefore, requiring trade openness. This result is similar to those from Le and Van (2020).
In light of the above results, there is a need to test the stability of the long-run relationship between variables, as shown by the inverse roots of $A R$ characteristic polynomial (Figure 1).

Figure 1 shows that all inverse roots lie within the unit circle. It implies that the long-run relationship between variables is stable; therefore, any energy policy response in this study could be validated.

The results from PVCM indicate that $\mathrm{CO}_{2}$ emissions, renewable energy consumption, and trade openness at lag one significantly influence agricultural value-added. Renewable energy consumption might favor agricultural growth, while $\mathrm{CO}_{2}$ emissions and trade openness would negatively affect. Trade openness in the context of globalization could facilitate technology transferability and input supply for agricultural development. It could also be a catalyst to the agricultural commodity market at the international level. Indeed, increasing the demand for renewable energy can increase agricultural production, and trade openness can be a catalyst in trading agricultural commodities and technology transfer for agricultural development. The negative sign might be explained by the fact that most of the agricultural products subject to international trade are exported as raw materials. The transformed goods from these raw materials are then imported for households' final consumption. In that case, importing more agricul-

Inverse roots of AR characteristic polynomial

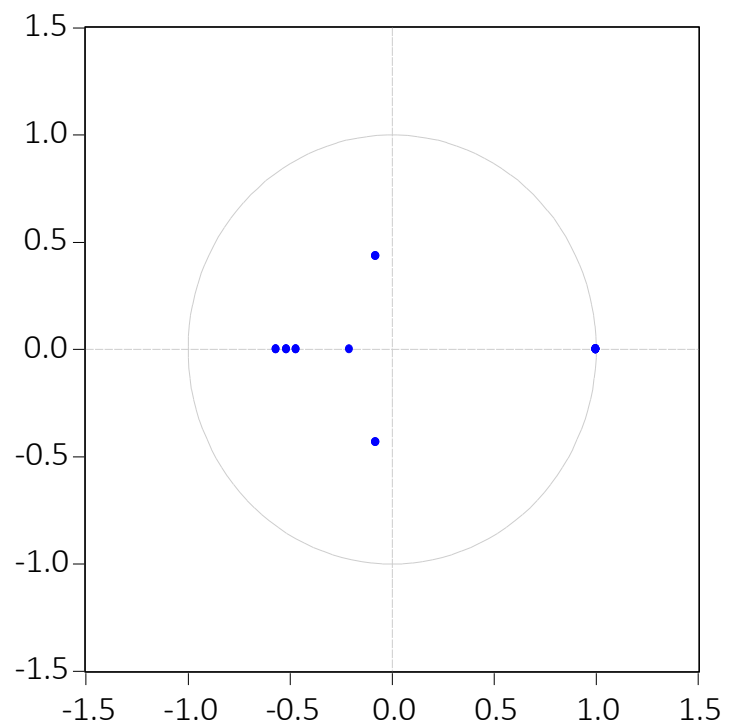

Figure 1. Test of stability of long-run relationship among variables 
tural commodities for households' consumption will favor mostly the agricultural development of net exporting countries while negatively affect the agriculture growth of net importer countries with low financial development (Kim et al., 2012). The other reason is sanitary and phytosanitary barriers that mostly face the agricultural commodities trade. Also, agricultural production subsidies in developed countries can lead to the negative impact of trade openness on agricultural development in developing countries, including the West
African countries. Reducing trade barriers can result in the expected impact of regional integration on countries' economies.

The second and fifth models indicate that there is no long-run causality relationship. The results show that agricultural value-added, renewable energy consumption, trade openness, and gross fixed capital formation do not significantly affect $\mathrm{CO}_{2}$ emissions. Similarly, the agricultural value-added, renewable energy consumption, trade

Response of DLNAGVA to Cholesky One S.D.DLNCO2 Innovation

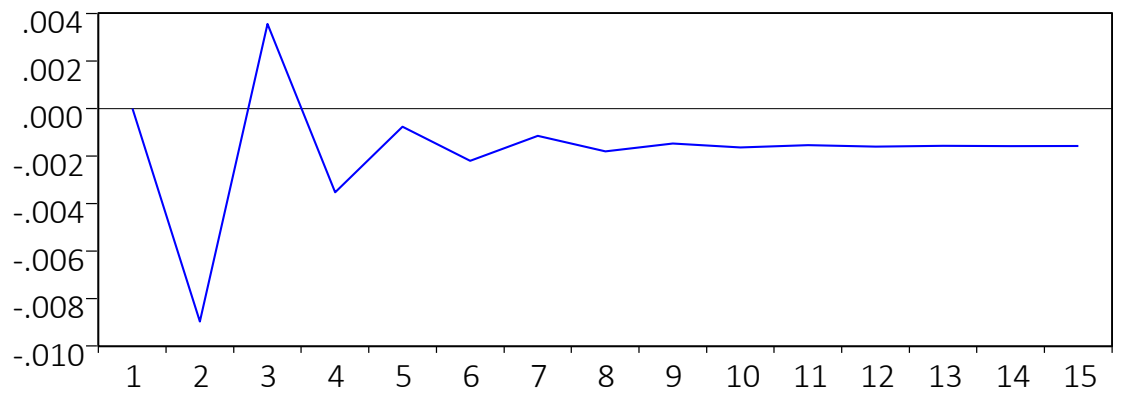

Figure $2 \mathrm{a} . \mathrm{CO}_{2}$ policy response on agricultural development by 2030 (SDG agenda)

Response of DLNAGVA to Cholesky

One S.D.DLNREC Innovation

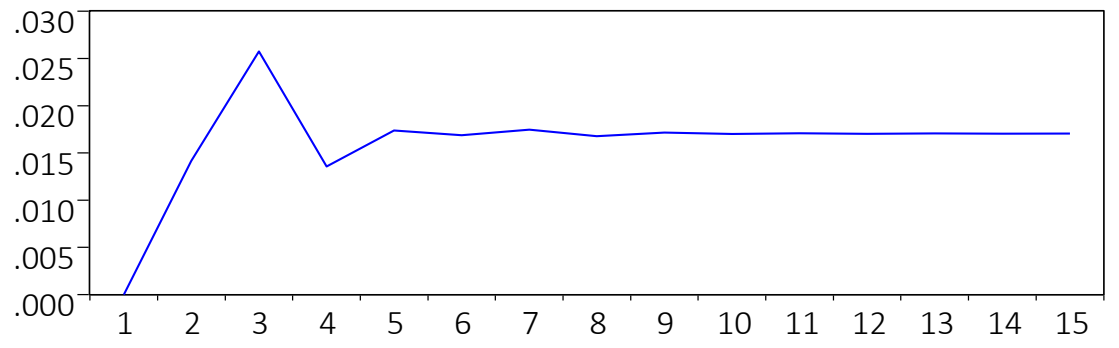

Figure 2b. REC policy response on agricultural development by 2030 (SDG agenda)

Response of DLNAGVA to Cholesky

One S.D.DLNTRADE Innovation

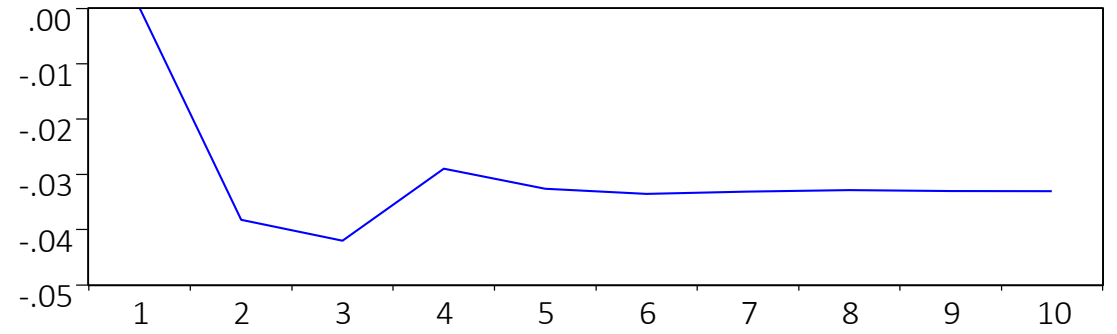

Figure 2c. Regional integration policy response on agricultural development by 2030 (SDG agenda) in West Africa 
Response of DLNAGVA to Cholesky

One S.D.DLNCO2 Innovation

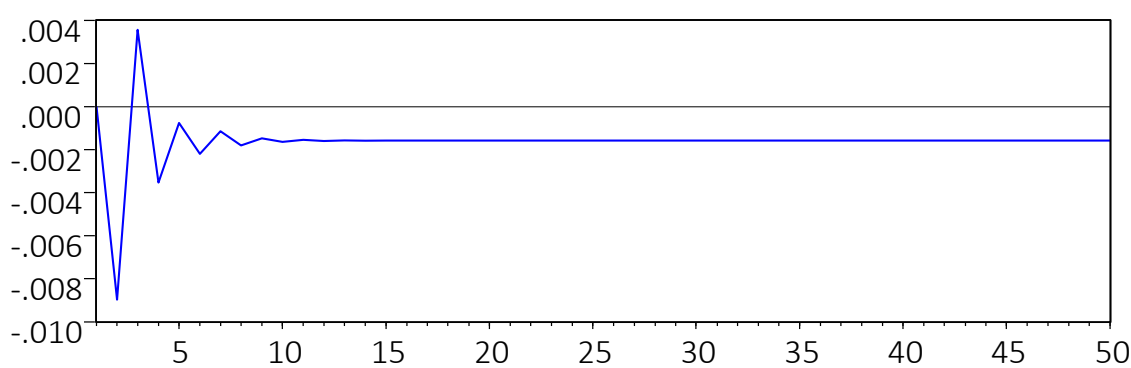

Figure 3a. $\mathrm{CO}_{2}$ emissions policy response on agricultural development by 2063 (African Union agenda)

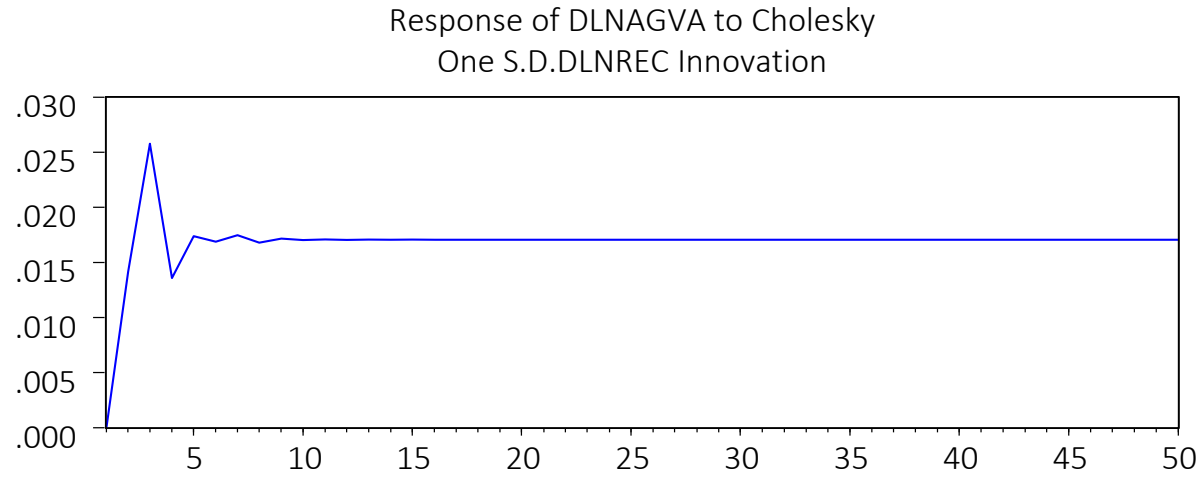

Figure 3b. REC policy response on agricultural development by 2063 (African Union agenda)

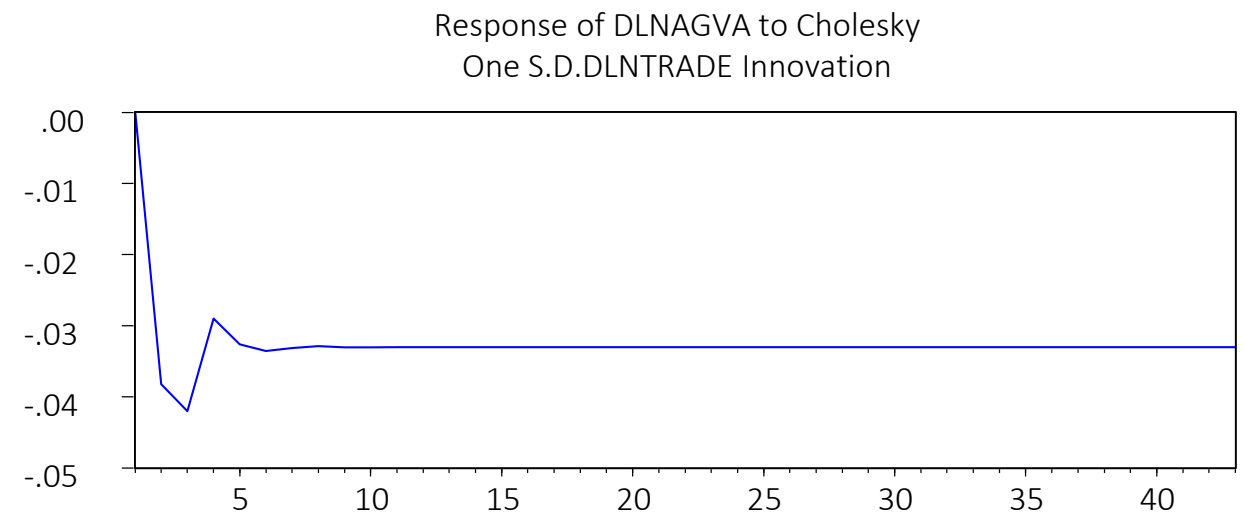

Figure 3c. Trade openness policy response on agricultural development by 2063 (African Union agenda)

openness, and $\mathrm{CO}_{2}$ emissions do not significantly affect gross fixed capital formation. However, the findings show that agricultural growth has positively affected trade openness, while there was a substitution between gross capital formation and trade openness.
In the specific context of West African countries, it becomes important to analyze the policy response of Sustainable Development Goals agenda (objective number 7) that seeks to ensure access to affordable, reliable, sustainable, and modern energy for all by 2030 with a focus on clean, renewable 


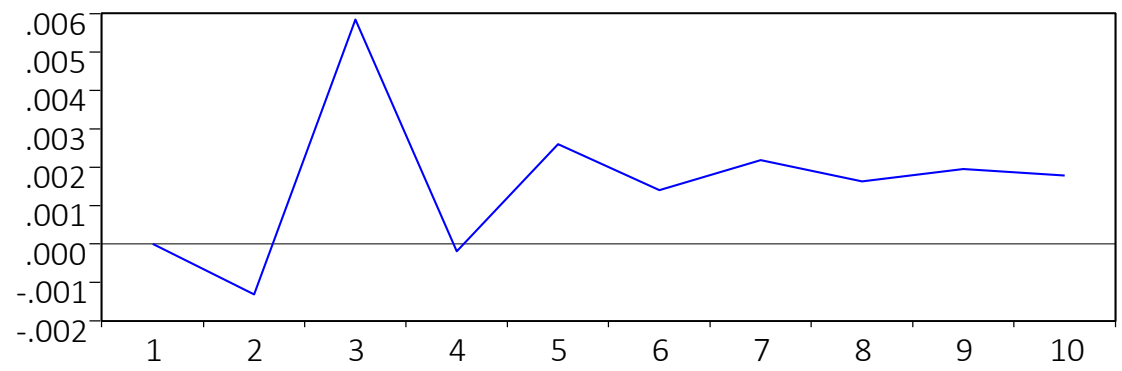

Figure 4a. Trade openness policy response on $\mathrm{CO}_{2}$ emissions by 2030 (SDG agenda)

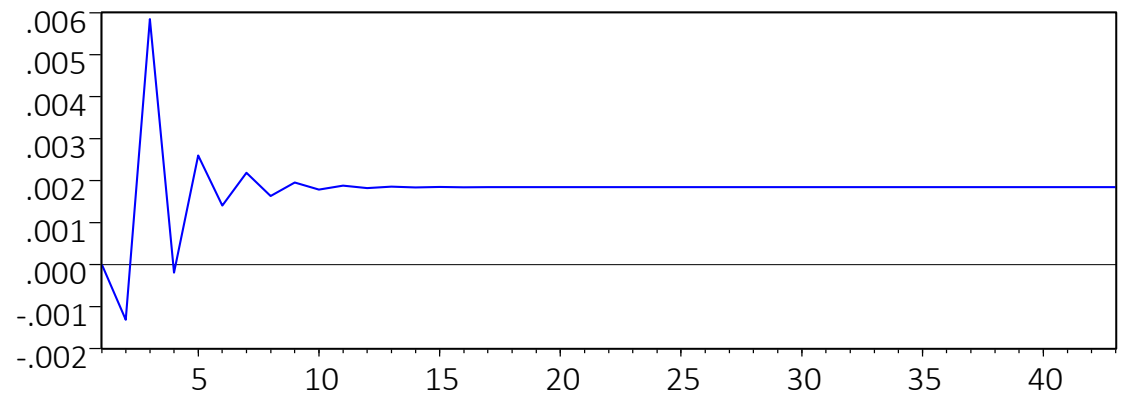

Figure 4b. Trade openness policy response on $\mathrm{CO}_{2}$ emissions by 2063 (African Union agenda)

energy use in combating climate change. Similarly, Agenda 2063 of the African Union has set a roadmap of environmentally sustainable and climate-resilient economies by increasing the use of renewable energy and fostering regional integration. Either SDG agenda (Figures 2a, 2b, and 2c) or Agenda 2063 of the African Union (Figures 3a, $3 \mathrm{~b}$, and $3 \mathrm{c}$ ), the impulse responses of an increase in $\mathrm{CO}_{2}, \mathrm{REC}$ and trade openness have similar trends. Figures $2 \mathrm{a}, 2 \mathrm{c}, 3 \mathrm{a}$, and $3 \mathrm{c}$ show that an increase in $\mathrm{CO}_{2}$ and trade openness considering the SDG agenda and African Union agenda will negatively affect the agricultural value-added of West African countries starting from 2023. However, an increase in REC will positively affect agricultural development. The high effect of the use of REC will be observed for the first three years and will start declining in the fourth year. After 5 years, the impact of REC on agriculture will remain constant but positive.

The results show that globalization through trade openness will increase $\mathrm{CO}_{2}$ emissions. Whether one considers the SDG agenda (Figure 4a) or the
African Union agenda (Figure 4b), similar trade openness effects on $\mathrm{CO}_{2}$ emissions are observed. These results corroborate those from Mutascu and Sokic (2020) and Sannasse and Seetanah (2016). The positive relationship between trade openness and pollution was also found by Bataka (2021) who found that globalization contributes to environmental pollution in Sub-Saharan African countries.

Trade openness can increase $\mathrm{CO}_{2}$ emissions if most imported goods are highly pollutants. Also, it is well recognized that developing countries like the West African countries have dirty industries with non-binding environmental laws in contrast to developed countries. These findings suggest that the impact of trade openness on $\mathrm{CO}_{2}$ emissions may depend on economic development; therefore, the re-examination of trade policy in developing countries toward a clean environment is needed for sustainable economic development. Findings also show that trade openness can increase renewable energy consumption, which can be used for agricultural production (see Figures A1 and A2 in Appendix A). 


\section{CONCLUSION}

The use of renewable energy is a key strategy in combating climate change, one of the most world's concerns of the century. In the context of developing countries where rapid population growth and urbanization are expected, renewable energy consumption (REC) must be encouraged to meet the increasing demand for energy while reducing $\mathrm{CO} 2$ emissions. Therefore, the new empirical evidence is needed for setting a roadmap of regional energy policy for economic development. However, the specific energy policy could depend not only on the type of hypothesis of the relationship between REC and economic development but also on the geographical position of the region and the main drive of countries' economies. In the context of developing countries, including the West African region, where the agricultural sector remains the main driver of countries' economies, not much attention has been given to the role of trade openness as a catalyst for RE technology transfer and REC in investigating the dynamic between $\mathrm{CO}_{2}$ emissions as the main source of climate change and agricultural development of the region. This study analyzes the relationship between $\mathrm{CO}_{2}$ emissions and agricultural development in West African countries by focusing on the role of renewable energy and trade openness.

The second-generation panel unit root tests, the Westerlund cointegration methods were used with the data from 13 countries of West Africa from 1990 to 2015. A panel error correction model was used to analyze the long-run relationship between variables. A panel Granger causality test was also used to check the causality direction between variables. Findings show a unidirectional relationship between agricultural value-added (AgVA) and $\mathrm{CO}_{2}$ emissions running from $\mathrm{CO}_{2}$ emissions to $\mathrm{AgVA}$. The unidirectional causality was also found from REC to agricultural value-added. The results confirm the unidirectional hypothesis running from the gross fixed capital formation (GFCF) to REC, on the one hand, and from GFCF to trade openness, on the other hand. Moreover, the bidirectional hypothesis is verified between agricultural development and trade openness with positive and significant effects. The results show that previous shocks on different variables might result in a negative effect on agricultural value-added and trade openness in the long-run. However, the results show that the previous shocks on agricultural value-added, $\mathrm{CO}_{2}$ emissions, gross fixed capital formation, and trade openness will increase the renewable energy demand by $7.6 \%$ in the long run. Considering the SDG agenda (Agenda 2030) or the African Union agenda (Agenda 2063), the impulse response of REC showed a positive effect on agricultural value-added while negatively related to $\mathrm{CO}_{2}$ emissions and trade openness. Increasing the demand for renewable energy can spur agricultural production, and trade openness can ease the trade of agricultural commodities. However, exporting more agricultural commodities as raw materials and importing mostly high pollutant commodities will result in a positive effect relationship between trade openness and $\mathrm{CO}_{2}$ emissions, as shown in the policy responses of Agenda 2030 and 2063 in the results. These results suggest that fostering renewable energy policy in West African countries will contribute to agricultural development. However, a re-examination of trade policy to reduce environmental pollution should be a priority for the West African countries to gain from the regional integration.

\section{AUTHOR CONTRIBUTIONS}

Conceptualization: Essossinam Ali.

Data curation: Essossinam Ali.

Formal analysis: Essossinam Ali.

Funding acquisition: Essossinam Ali.

Investigation: Essossinam Ali.

Methodology: Essossinam Ali.

Project administration: Essossinam Ali.

Resources: Essossinam Ali.

Software: Essossinam Ali.

Supervision: Essossinam Ali. 
Validation: Essossinam Ali.

Visualization: Essossinam Ali.

Writing - original draft: Essossinam Ali.

Writing - review \& editing: Essossinam Ali.

\section{ACKNOWLEDGMENT}

The author wants to thank Dr. Moukpè GNINIGUE for his technical supports and Prof. Jean Marcelin Bosson BROU from the University of Houphouet Boigny (Cote d'Ivoire), Dr. Odzadifo K. WONYRA and Dr. Hodabalo BATAKA from the University of Kara, Dr. Koffi Massesso ADJI from the West African Sciences Services Centre on Climate Change and Land Use (University of Cheikh Anta Diop, Dakar) and Essotanam MAMBA from the University of Lomé for their constructive comments on the earlier version of this manuscripts. Finally, the author is grateful to the anonymous reviewers and Editor-inChief of Environmental Economics, whose comments have improved this paper. However, the opinions expressed in this paper are solely those of the author.

\section{REFERENCES}

1. Adelaja, S., \& Hailu, H. (2008). Renewable energy development and implications to agricultural viability. In Proceedings of the American Agricultural Economics Association (AAEA) Conference. Orlando, FL.

2. Ali, E. (2018). Impact of climate variability on staple food crop production in northern Togo. Journal of Agriculture and Environment for International Development, 112(2), 321-341. Retrieved from https://mpra. ub.uni-muenchen.de/91972/1/ MPRA_paper_91972.pdf

3. Ali, E., Egbendewe, A. Y. G., Abdoulaye, T., \& Sarpong, D. B. (2020). Willingness to pay for weather index-based insurance in semi-subsistence agriculture: evidence from northern Togo. Climate Policy, 20(5), 534-547. https://doi.org/10.1080/14693062. 2020.1745742

4. Alp, E. A. (2016). Energy consumption and economic growth in OECD countries. International Journal of Energy Economics and Policy, 6(4), 753-759. Retrieved from https://ideas.repec.org/a/eco/ journ2/2016-04-11.html

5. Bataka, H. (2021). Globalization and environmental pollution in Sub-Saharan Africa. African Journal of Economic Review, 9(1),
191-213. Retrieved from https:// www.ajol.info/index.php/ajer/article/view/201943

6. Bayale, N., Ali, E., Tchagnao, A., \& Nakumuryango, A. (2021). Determinants of renewable energy production in WAEMU countries: New empirical insights and policy implications. International Journal of Green Energy. Retrieved from https://doi.org/10.1080/15435075.2 021.1875467

7. Bayrakci, A. G., \& Koçar, G. (2012). Utilization of renewable energies in Turkey's agriculture. Renewable and Sustainable Energy Reviews, 16(1), 618-633. https://doi. org/10.1016/j.rser.2011.08.027

8. Ben Jebli, M., \& Ben Yousef, S. (2015). The role of renewable energy and agriculture in reducing CO2 emissions: Evidence for North Africa Countries (MPRA Paper No. 68477). Retrieved from https:// mpra.ub.uni-muenchen.de/68477/

9. Ben Jebli, M., \& Ben Yousef, S. (2017). Renewable energy consumption and agriculture: evidence for cointegration and Granger causality for Tunisian economy. International Journal of Sustainable Development \& World Ecology, 24(2), 149-158. https:// doi.org/10.1080/13504509.2016.1 196467

10. Bhattacharya, M., Paramati, S. R., Ozturk, I., \& Bhattacharya, S.
(2016). The effect of renewable energy consumption on economic growth: the evidence from top 38 countries. Applied Energy, 162, 733-741. https://doi.org/10.1016/j. apenergy.2015.10.104

11. Birol, F. (2007). Energy economics: A place for energy poverty in the agenda? The Energy Journal, 28(3), 1-6. Retrieved from http://www.iaee.org/en/publications/ejarticle. aspx? $\mathrm{id}=2218$

12. Breusch, T., \& Pagan, A. (1980). The Lagrange Multiplier test and its application to model specification in econometrics. Review of Economic Studies, 47(1), 239-253. https://doi. org/10.2307/2297111

13. Brini, R., Amara, M., \& Jemmali, H. (2017). Renewable energy consumption, International trade, oil price and economic growth inter-linkages: the case of Tunisia Renewable Sustainable Energy Reviews, 76, 620-627. https://doi. org/10.1016/j.rser.2017.03.067

14. Brundtland, G. H. (1987). Our common future - call for action. Environmental Conservation, 14(4), 291-294. https://doi.org/10.1017/ S0376892900016805

15. Chel, A., \& Kaushik, G. (2011). Renewable energy for sustainable agriculture. Agronomy for Sustainable Development, 31, 
91-118. Retrieved from https:// link.springer.com/article/10.1051/ agro/2010029

16. FAO \& AfDB. (2015). Agriculture in West Africa: Market and policy drivers. In F. Hollinger \& J. M. Staatz (Eds.), African Development Bank and Food and Agriculture Organization of the United Nations. Retrieved from https://www.afdb. org/fileadmin/uploads/afdb/ Documents/Publications/Agricultural_Growth_in_West_Africa_-_Market_and_policy_drivers_-_OSAN.pdf

17. Farajian, L., Moghaddasi, R., \& Hosseini, S. (2018). Agricultural energy demand modeling in Iran: Approaching to a more sustainable situation. Energy Reports, 4, 260265. Retrieved from https://www. econstor.eu/handle/10419/187920

18. Frangou, M., Aryblia, M., Tournaki, S., \& Tsoutsos, T. (2018). Renewable energy performance contracting in the tertiary sector standardization to overcome barriers in Greece. Renewable Energy, 125, 829-839. https://doi. org/10.1016/j.renene.2018.03.001

19. Heidari, N., \& Pearce, J. M. (2016). A review of greenhouse gas emissions liabilities as the value of renewable energy for mitigating lawsuits for climate change related damages. Renewable and Sustainable Energy Reviews, 55(C), 899-908. https://doi.org/10.1016/j. rser.2015.11.025

20. Hickel, J., \& Kallis, G. (2020). Is green growth possible? New Political Economy, 25(4), 469-486. https://doi.org/10.1080/13563467. 2019.1598964

21. Hohmeyer, O., \& Bohm, S. (2015). Trends toward $100 \%$ renewable electricity supply in Germany and Europe: a paradigm shift in energy policies. WIREs Energy and Environment, 4(1), 74-97. https:// doi.org/10.1002/wene.128

22. Hoyos, R. E., \& Sarafidis, V. (2006). Testing for cross-sectional dependence in panel-data models. The Stata Journal, 6(4), 482-496. Retrieved from https://econpapers.repec.org/article/tsjstataj/v_ 3a6_3ay_3a2006_3ai_3a4_3ap_ 3a482-496.htm
23. Inglesi-Lotz, R. (2016). The impact of renewable energy consumption to economic growth: a panel data application. Energy Economics, 53, 58-63. https://doi.org/10.1016/j. eneco.2015.01.003

24. International Energy Agency (IEA). (2014). Africa energy outlook: a focus on energy prospects in Sub-Saharan Africa. World energy outlook special report. IEA/OECD, Paris.

25. IRENA. (2015). Africa 2030: Roadmap for renewable energy future. Abu Dhabi.

26. IRENA. (2018). Renewable energy auctions: cases from Sub-Saharan Africa. Abu Dhabi.

27. Jenniches, S. (2018). Assessing the regional economic impacts of renewable energy sources: A literature review. Renewable and Sustainable Energy Reviews, 93, 35-51. https://doi.org/10.1016/j. rser.2018.05.008

28. Kahia, M., Ben Aïssa, M. S., \& Lanouar, C. (2017). Renewable and non-renewable energy useeconomic growth nexus: The case of MENA net oil importing countries. Renewable and Sustainable Energy Reviews, 71, 127-140. https://doi.org/10.1016/j. rser.2017.01.010

29. Khan, M. T. I., Ali, Q., \& Ashfaq, M. (2018). The nexus between greenhouse gas emissions, electricity production, renewable energy and agriculture in Pakistan. Renewable Energy, 118, 437-451. https://doi.org/10.1016/j.renene.2017.11.043

30. Kim, D.-H., Lin, S.-C., \& Suen, Y.-B. (2012). The simultaneous evolution of economic growth, financial development and trade openness. The Journal of International Trade and Economic Development, 21(4), 513-537. https://doi.org/10.1080/09638199. 2010.497933

31. Kuznets, S. (1955). Economic growth and income inequality. American Economic Review, 45(1), 1-28. Retrieved from https://www. jstor.org/stable/1811581

32. Le, H. P., \& Van, D. T. B. (2020). The energy consumption structure and African EMDEs sustainable development. Heliyon, 6(4), e03822. https://doi.org/10.1016/j. heliyon.2020.e03822

33. Liu, X., Zhang, S., \& Bae, J. (2017a). The impact of renewable energy and agriculture on carbon dioxide emissions: Investigating the environmental Kuznets curve in four selected ASEAN countries. Journal of Cleaner Production, 164, 1239-1247. https://doi. org/10.1016/j.jclepro.2017.07.086

34. Liu, X., Zhang, S., \& Bae, J. (2017b). The nexus of renewable energy-agriculture-environment in BRICS. Applied Energy, 204, 489-496. https://doi.org/10.1016/j. apenergy.2017.07.077

35. Lyytimäki, J. (2018).

Renewable energy in the news: Environmental, economic, policy and technology discussion of biogas. Sustainable Production and Consumption, 15(1), 65-73. https:// doi.org/10.1016/j.spc.2018.04.004

36. Martinho, V. J. P. D. (2016). Energy consumption across European Union farms: Efficiency in terms of farming output and utilized agricultural area. Energy, 103, 543-556. https://doi. org/10.1016/j.energy.2016.03.017

37. Martinho, V. J. P. D. (2018). Interrelationships between renewable energy and agricultural economics: an overview. Energy Strategy Reviews, 22, 396409. https://doi.org/10.1016/j. esr.2018.11.002

38. Meadows, D. H., Meadows, D. L., Rander, J., \& Behrens, W. W. (1972). The limits of growth. New York.

39. Miketa, A., \& Merven, B. (2013). West African power pool: Planning and prospects for renewable energy. Abu Dhabi: IRENA. Retrieved from https://www.irena.org/-/media/Files/IRENA/Agency/Publication/2013/WAPP.pdf

40. Mutascu, M., \& Sokic, A. (2020). Trade openness - $\mathrm{CO} 2$ emissions nexus: a wavelet evidence from EU. Environmental Modelling and Assessment, 25, 411-428. https:// doi.org/10.1007/s10666-02009689-8 
41. O’Brien, R. M. (2007). A Caution Regarding Rules of Thumb for Variance Inflation Factors. Quality and Quantity, 41, 673-690. https:// doi.org/10.1007/s11135-0069018-6

42. Ouedraogo, N. (2013). Energy consumption and economic growth: the evidence from Economic Community of West African States (ECOWAS). Energy Economics, 36, 637-647. https://doi.org/10.1016/j.eneco.2012.11.011

43. Paramati, S. R., Apergis, N., \& Ummalla, M. (2018). Dynamics of renewable energy consumption and economic activities across the agriculture, industry, and service sectors: evidence in the perspective of sustainable development. Environmental Science and Pollution Research, 25(2), 1375-1387. https://doi. org/10.1007/s11356-017-0552-7

44. Parkes, B., Sultan, B., \& Ciais, P. (2018). The impact of future climate change and potential adaptation methods on maize yields in West Africa. Climatic Change, 151, 205-217. https://doi. org/10.1007/s10584-018-2290-3

45. Pesaran, M. H. (2007). A simple panel unit root test in the presence of cross-section dependence. Journal of Applied Econometrics, 22(2), 265-312. https://doi. org/10.1002/jae.951

46. Proskuryakova, L. (2018). Updating energy security and environmental policy: energy theories revisited. Journal of Environmental Management, 233, 203-214. https://doi.org/10.1016/j. jenvman.2018.06.016

47. Raeeni, A. A. G., Hosseini, S., \& Moghaddasi, R. (2019). How energy consumption is related to agricultural growth and export: an econometric analysis on Iranian data. Energy Reports, 5, 50-53. https://doi.org/10.1016/j. egyr.2018.11.005

48. Rafindadi, A. A., \& Ozturk, I. (2017). Impacts of renewable energy consumption on German economic growth: Evidence from combined cointegration test. Renewable and Sustainable Energy
Reviews, 75, 1130-1141. https://doi. org/10.1016/j.rser.2016.11.093

49. Reilly, J. M. (2012). Green growth and efficient use of natural resources. Energy Economics, 34(1), 85-93. https://doi. org/10.1016/j.eneco.2012.08.033

50. Resch, G., Held, A., Faber, T., Panzer, C., Toro, F., \& Haas, R. (2008). Potentials and prospects for renewable energies at global scale. Energy Policy, 36(11), 40484056. https://doi.org/10.1016/j. enpol.2008.06.029

51. Sadiqa, A., Gulagi, A., \& Breyer, C. (2018). Energy transition roadmap towards $100 \%$ renewable energy and role of storage technologies for Pakistan by 2050. Energy, 147, 518-533. https://doi.org/10.1016/j. energy.2018.01.027

52. Sannasse, R. V., \& Seetanah, B. (2016). Trade openness and CO2 emission: evidence from SIDS. In Ramiah and Gregoriou (Eds.), Handbook of Environmental and Sustainable Finance (pp. 165-177).

53. Schwerhoff, G., \& Sy, M. (2017). Financing renewable energy in Africa: Key challenge of Sustainable Development Goals. Renewable and Sustainable Energy Reviews, 75, 393-401. https://doi. org/10.1016/j.rser.2016.11.004

54. Sutherland, L. A., Peter, S., \& Zagata, L. (2015). Conceptualising multi-regime interactions: the role of agriculture in renewable energy transitions. Research Policy, 44(8), 1543-1554. https://doi. org/10.1016/j.respol.2015.05.013

55. Van Linden, V., \& Herman, L. (2014). A fuel consumption model for off-road use of mobile machinery in agriculture. Energy, 77, 880-889. https://doi. org/10.1016/j.energy.2014.09.074

56. WDI. (2020). World Development Indicators. World Bank, Washington D.C. Retrieved from https://databank.worldbank.org/ source/world-developmentindicators

57. Wesseh, P. K., \& Lin, B. (2016). Can African countries efficiently build their economies on renewable energy? Renewable and Sustainable Energy Reviews, 54,
161-173. https://doi.org/10.1016/j. rser.2015.09.082

58. Westerlund, J. (2007). Testing for error correction in panel data. Oxford Bulletin of Economics and Statistics, 69(6), 709-748. https://doi.org/10.1111/j.14680084.2007.00477.x

59. Zaccour, G., \& Oubraham, A. (2018). A survey of application of viability theory to the sustainable exploitation of renewable resources. Ecological Economics, 145, 346-367. https://doi.org/10.1016/j.ecolecon.2017.11.008 


\section{APPENDIX A}

Response to Cholesky One S.D. Innovations
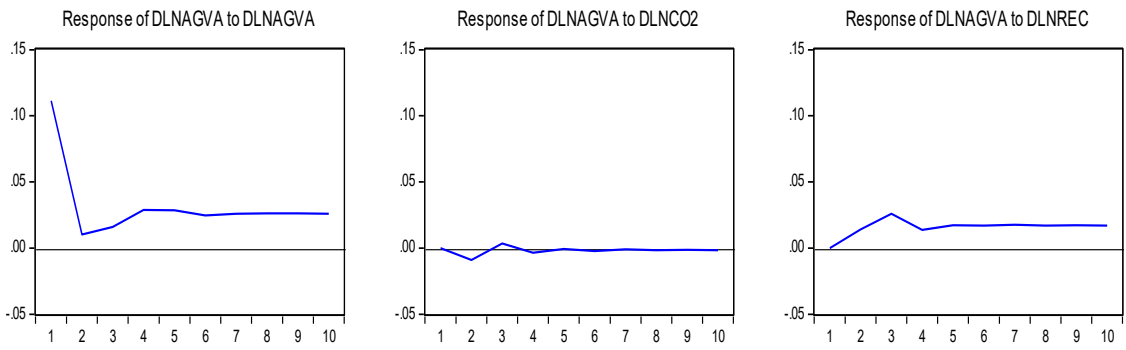

Response of DLNAGVA to DLNTRADE
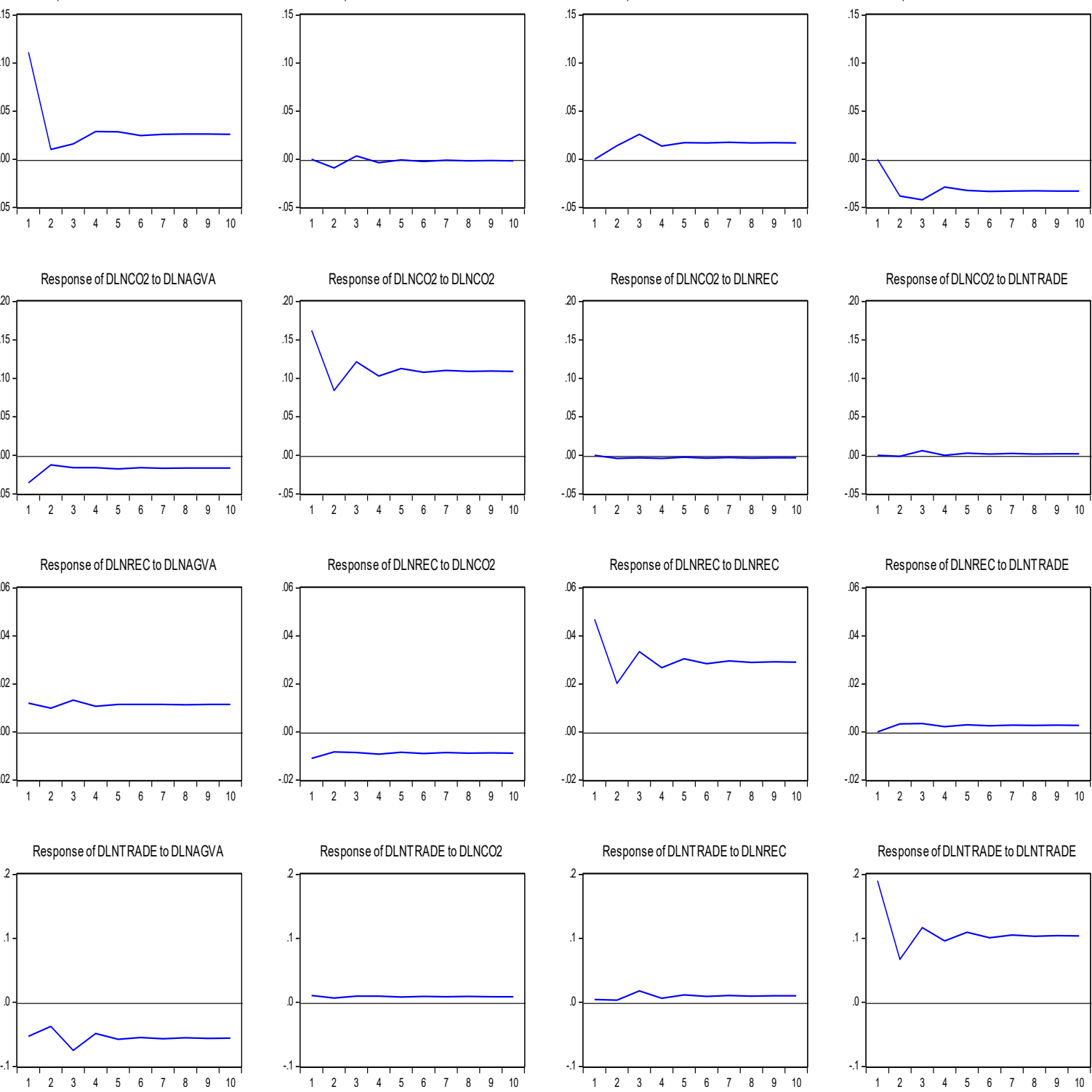

Figure A1. Policy responses in light of sustainable development agenda (Agenda 2030) 
Response to Cholesky One S.D. Innovations
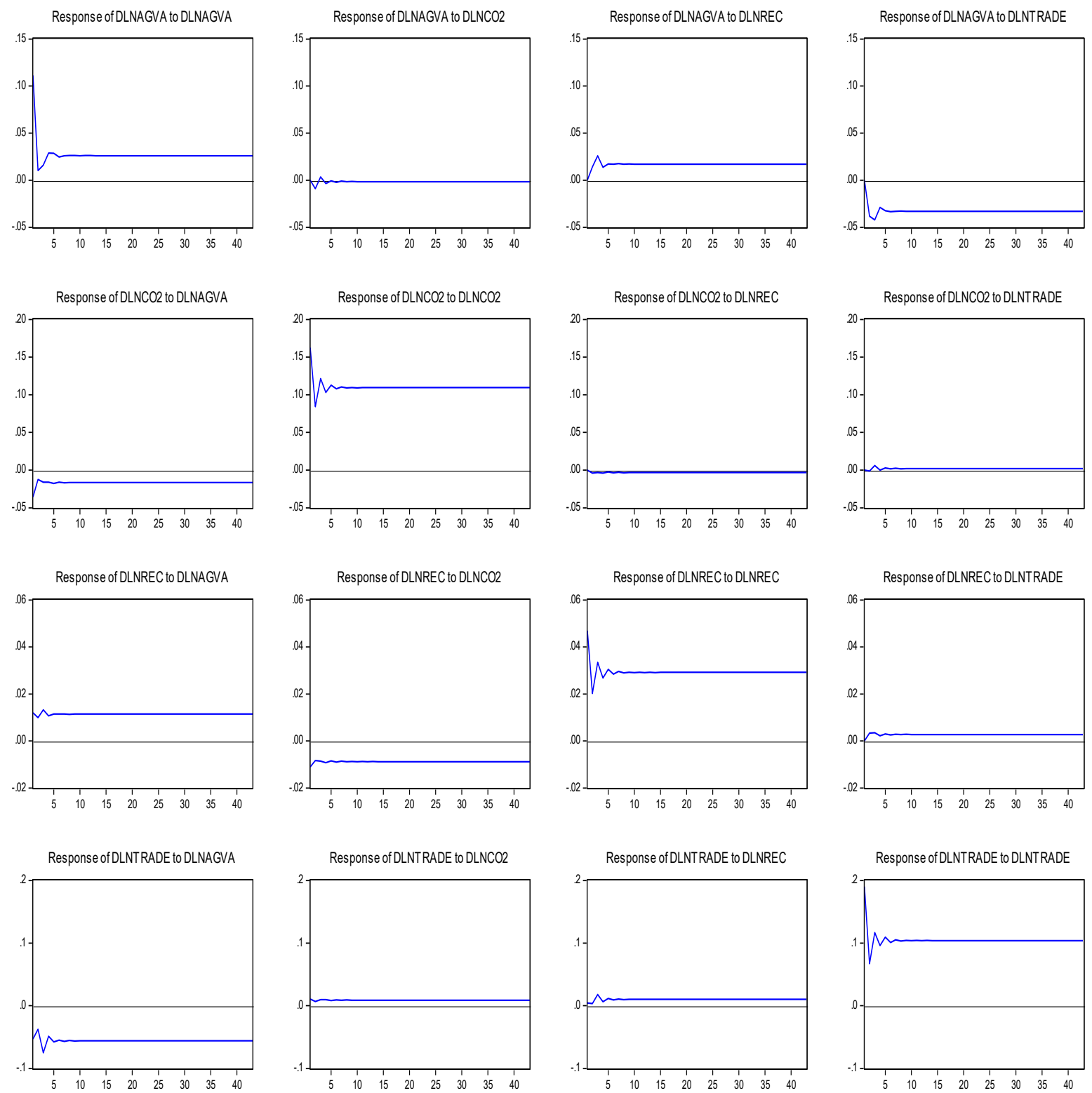

Figure A2. Policy response in light of African Union agenda (Agenda 2063) 